\title{
Stories of resistance in Greek street art: A cognitive-semiotic approach
}

\begin{abstract}
Georgios Stampoulidis
In line with cognitive semiotics, this paper suggests a synthetic account of the important but controversial notion of narrative (in street art, and more generally): one that distinguishes between three levels: (a) narration, (b) underlying story, and (c) frame-setting. The narrative potential of street art has not yet been considerably studied in order to offer insights into how underlying stories may be reconstructed from the audience and how different semiotic systems contribute to this. The analysis is mainly based on three contemporary street artworks and two political cartoons from the 1940s, involving the same frame-setting, which may be labeled as "Greece vs. Powerful Enemy." The study is built on fieldwork research that was carried out during several periods in central Athens since 2014. The qualitative analyses with the help of insights from phenomenology show that single static images do not narrate stories themselves (primary narrativity), but rather presuppose such stories, which they can prompt or trigger (secondary narrativity). Notably, the significance of sedimented socio-cultural experience, collective memory and contextual knowledge that the audience must recruit in order to reconstruct the narrative potential through the process of secondary narrativity is stressed.
\end{abstract}

Keywords: narrative, narration, street art, phenomenology, primary/secondary narrativity

\section{Introduction}

Collective identities are not only revealed and consolidated through language, but also through depiction. Such cultural constructions are often established and reinforced by underlying stories, where events or situations are temporally and casually ordered. Language-based narratives have been frequently studied since the pioneering work of Propp (1928/1968), while pictorial ones have received comparably less attention in general. ${ }^{1}$ Attempts to elucidate the cognitive semiotic basis of pictorial narrativity, especially in static images such as street artworks, have been relatively rare. In the present paper I undertake this attempt with the help of cognitive semiotics, a comparatively recent discipline, which integrates methods, models, and concepts from three research fields: cognitive linguistics, cognitive science and semiotics. Cognitive semiotics is informed by phenomenology, the systematic study of human experience (Sokolowski, 2008; Sonesson, 2009; Zlatev, 2015; Zlatev et al., 2016). Given that "phenomenology is a method of description [and] as such, it should really be considered an empirical method" (Sonesson, 2009, p.127), such description is fundamental for conceptualizing the phenomenon under investigation, notably pictorial narrativity.

The paper focuses upon the political use of street art in contemporary Greece as a form of visual expression of resistance in urban space, in relation to the Eurozone crisis. Street art includes a plethora of creative practices and visual interventions in the urban environment applying a wide variety of types, such as paste-ups, posters, stickers, drawings, murals, cut outs and stencils (e.g. Bengtsen, 2014; Chaffee, 1993; Lewisohn, 2008; Philipps, 2015; Tulke, 2016; Young, 2016; Zaimakis, 2015) for addressing (but not limited to) socio-political issues within certain contextual surroundings. Although the scope of this paper does not allow to deal with these issues in detail, it is important to bear in mind the socio-political and cultural context where this kind of street art emerged, namely in 2008 following the "austerity crisis" within Greece and the EU.

\footnotetext{
${ }^{1}$ Nevertheless, as pointed out by an anonymous reviewer, this may be not the case in art history, given Albertin's declaration since 1435 that "the great work of the painter is the narrative" or the historia (Christiansen, 1983).
} 
I propose that recent Greek street art visualizes in numerous cases a confrontational situation of "Greece against a Powerful Other," with historical parallels. This serves as a frame-setting, which may be understood as an umbrella notion for shared beliefs and ideologies, collective memory (Halbwachs, 1992/1952; Werstch, 2002) and shared myths (Levi-Strauss, 1973/1967). This emerges and becomes consolidated over time through repetition and manifestations in various semiotic systems such language and depiction, instantiated in a number of media such as street art and political cartoons. ${ }^{2}$

The analysis presented here relies upon the author's empirical material, including photo documentation and go-along interviews with street artists, gathered during the years of ethnographic research undertaken in Athens at different periods between 2015 and 2018. ${ }^{3}$ For the reader interested in gaining access to the corpus of 45 street artworks, an online repository on the Open Science Framework (OSF) platform has been constructed. ${ }^{4}$ For the sake of brevity, the qualitative analysis here is mainly based on three street artworks, illustrating the same sedimented socio-cultural frame-setting. The analysis is further supported with the help of two historically preceding examples from the 1940s, manifested in another medium: political cartoons. Of course, the particularities of street artworks and political cartoons need to be acknowledged, since they belong to recognizable different genres, "being governed by discourse-internal factors as well as situational/pragmatic understanding" (Forceville and Kjeldsen, 2018, p.158) and specific genre conventions. Nevertheless, both constitute exemplary categories to make the point that they thematize similar underlying "stories of resistance."

The scope of the present paper is both theoretical and empirical. Theoretically, I propose a concrete and applicable schema for analyzing narrative in two different media, namely street art and political cartoons, consisting of the following levels: (a) narration, (b) underlying story, and (c) frame-setting. Empirically, this schema is applied to the five images instantiated in both media.

The paper's structure is as follows. In Section 2, a definiton of street art sufficient for present purposes is provided and in Section 3, the conceptual schema for narratological analysis with specific reference to contemporary Greek street art and political cartoons from the 1940s is presented. Sections 4-6 provide the analysis and in Section 7 I summarize the main findings of the research, ending with suggestions for possible future paths in this field.

\section{Street Art in Focus}

The phenomena of street art and graffiti, as complex manifestations of human cultural consciousness and meaningful artistic and social practices, have been subject to discussions and controversies for the past two decades (for a review see Avramidis and Tsilimpounidi, 2017). These discussions have focused upon issues of creativity, performativity, anonymity, illegality, ephemerality and site-and-time-specificity, but also on the nature of social activism. It is important to understand for what reasons street art and graffiti exist as movements that insist on occupying urban space and to discuss the differences between these media, since practitioners of street art and graffiti themselves draw demarcation lines between them. To simplify, we may

\footnotetext{
${ }^{2}$ Semiotic systems can in general be defined as signs with in-system specific affordances and interrelations and include language, depiction (still and moving images) and gesture (Stampoulidis et al., 2019; Zlatev, 2019). In narratological terms, narratives may be expressed in all these three semiotic systems (Prince, 1982).

${ }^{3}$ This phenomenologically inspired method for the study of human experience is based on freely emerged dialogue between two discussants (the researcher-interviewer and the street artist-interviewee), as introduced by Pollio et al. (1997) in conjunction with Kusenbach's (2003) suggestions about go-along interviews. The so-called go-along interviewing is an innovative methodological approach to obtain contextualized real-time perspectives, by facilitating access to street artists' experiences and practices as they unfold in real time and space (see Stampoulidis, in preparation).

${ }^{4}$ See URL: https://osf.io/nykr6/ (Retrieved 17 June 2019).
} 
regard the two media as contemporary variants of urban creativity in general (Ross J. I. et al., 2017), being separate, but to some extent overlapping.

The following characteristics of street art can be argued to be central (Bengtsen, 2014; Blanché, 2015; Hansen and Flynn, 2016; Hoppe, 2014):

- Openness in the sense of its installment in the urban environment, and availability to a wide audience. $^{5}$

- Being unsanctioned in the sense that street artists intervene, either legally or illegally, in the urban space without external fundings and sponsors, by making the urban environment a site for exploration and potential change since they never become routine.

- Ephemerality in the sense that street art is not meant to last for long, as artworks continuously change and evolve throughout time, or may be just removed.

- Playfulness in the sense of creativity and potential rhetoricalness (for an analysis of metaphors and other rhetorical figures in street art, see Stampoulidis et al., 2019; Stampoulidis and Bolognesi, in press).

- Contemporariness in the sense that street art is supposedly part-and-parcel of what is happening in a society in a specific time and space. Thus, street art may reflect and visualize significant societal events and situations by evoking the reconstruction of underlying stories.

Street art practices have undeniably opened new ways of understanding and experiencing the urban fabric of everyday life, considering the economic and socio-political circumstances within which they are placed. So called "street art of resistance" (Awad and Wagoner, 2017), the socio-cultural practice of street art as a new form of activism and political struggle, has the unique ability to trace political and cultural tensions mediating historical and socio-political underlying stories into the surface of the city towards new "spaces of hope" (Harvey, 2000; Novy and Colomp, 2013).

In short, street art may be understood as an open, unsanctioned, ephemeral, creative and contemporary socio-cultural medium in urban space, that typically incorporates two interacting semiotic systems (language and depiction), and thus, polysemiotic (Stampoulidis et al., 2019; Zlatev, 2019), often addressing, but not limited to, socio-political issues.

\section{On Pictorial Narrativity: A Cognitive-Semiotic Approach}

What constitutes a narrative has been extensively debated within research in narratology, (the term for the field of narrative studies, introduced by Todorov in 1969). Despite decades of research, in diverse fields such cognitive science and psychology (e.g. Fludernik, 1996), enactive cognition (e.g. Caracciolo, 2013, 2014; Popova, 2015), film, audio description and drama studies (Bordwell, 2007; Diget, 2019; Vercauteren, 2012), history, philosophy and sociology (e.g. Todorov, 1969, 1971), literary studies (e.g. Genette, 1988; Prince, 1982, 2008; Schmid, 2010) and art history and semiotics (e.g. Ranta, 2011, 2013; Sonesson, 1997), there is still no consensus on the matter. Furthermore, the narrative potential of street art has not yet been considerably studied in order to offer insights into how underlying stories may be reconstructed and how different semiotic systems contribute to this.

To improve on this situation, I employ the conceptual-empirical loop of cognitive semiotics, which implies a virtuous alternation of conceptual analyses and empirical testing (Zlatev, 2015). This implies to start with experience-driven conceptual analysis, as a preliminary step to the study of empirical material (in this case, examples of contemporary

\footnotetext{
${ }^{5}$ For the aspect of walking in the city as a participatory experience of everyday urban fabric, see e.g. Ferrel and Weide (2010) and Hoppe (2014).
} 
Greek street art and historically preceding examples of political cartoons from the 1940s), and then return to the concepts with clarifications. This methodological approach, illustrated in Figure 1, encourages us to begin with the basic phenomenological principle to "look at" the phenomenon under investigation with as few theoretical preconceptions as possible, and to describe the way it is experienced. Then, we utilize theoretical tools, possibly from different frameworks, which help make this experience more explicit. Only then can an empirical analysis of the phenomenon based be formulated. Finally, we return to the concepts we started with, and the theories we adopted, with enriched understanding.

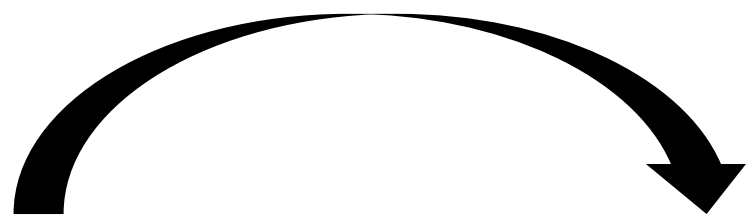

Conceptual: What is narrative (in street art and political cartoons)?
Empirical: How does it manifest itself in street art and political cartoons?

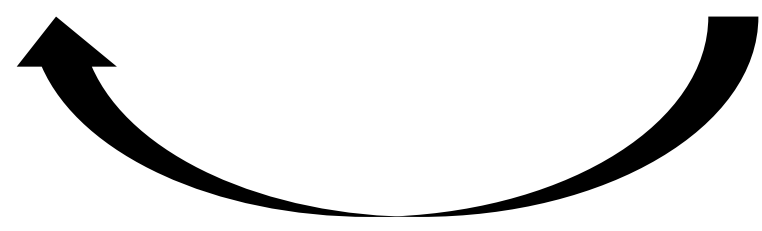

Figure 1. The conceptual-empirical loop applied to narrative in street art and political cartoons (adapted from Zlatev 2015: 1058).

To start with the most general "what" question: What is narrative? ${ }^{6}$ A typical definiton of narrative from the side of classical structural narratology is given by Abbott (2002, p.13): "the representation of an event or series of events." This is arguably much too general. On the other hand, Ryan (2007) argues for a fuzzy-set definition of narrative that amounts to several dimensions, including spatial, temporal, mental, formal, and pragmatic. Those dimensions "offer a toolkit for do-it-yourself definitions" (Ryan, 2007, p.30), which opens the doors to vagueness. More specifically, classical narratology insists that there are at least two different levels, or aspects of narrative, captured by the notions of syuzhet and fabula, elaborated by the Russian formalists (Bordwell, 2007; Vercauteren, 2012; Stam et al., 1992). Others have made analogous dichotomies to analyze the structure of fictional texts: recit vs. histoire (Genette, 1988), discourse vs. story (Chatman, 1978), story vs. fabula (Bal, 1997). As can be seen, however, the terminology differs fundamentally, and may lead to confusions.

On the other side, most recent cognitive narratology reconsiders the notion of narrative through the interactions of text and mind, drawing insights from cognitive linguistics, cognitive science and discourse analysis. This is a position first proposed and developed by Fludernik (1996) through the notion of experientiality in order to address the relationship between

\footnotetext{
${ }^{6}$ For the sake of brevity, I do not draw on a detailed historical overview of the study of narrative within and across related disciplines. What I discuss instead is how different theoretical strands relate to the definition of narrative proposed in this article.
} 
narrative and real-life experience, and then, elaborated in subsequent work by Caracciolo (2014) and Popova (2015) through the notions of experiential background and enaction, respectively. ${ }^{7}$

In the spirit of cognitive semiotics, it is possible to integrate elements of these different perspectives. Following the conceptual-empirical loop (see above), we may affirm the general principle of both cognitive narratology and phenomenology to start with: "human experience and of the ways things present themselves to us in and through such experience" (Sokolowski, 2000, p.2). One main implication from such phenomenological influence for our present purposes is the central idea that since we live in an intersubjective lifeworld (Sonesson, 2009), we use our deeply sedimented socio-cultural lifeworld knowledge to make sense of our experiences.

In the second step, we may address the numerous disagreements regarding the definition of narrative through a non-restrictive and synthetic definition that borrows from both classical (e.g. Chatman, 1978; Genette, 1988; Prince, 1982, 2008; Schmid, 2010; Todorov, 1971) and cognitive (e.g. Caracciolo, 2014; Fludernik, 1996; Popova, 2015) narratology. Crucially, however, to obtain this definition, it was necessary to analyze the street art images found in the corpus sample, identifying the narrative potential and how this was manifested (the empirical side of the loop). Only then, a productive definition of narrative could be reached (back to the conceptual side of the loop). Namely, narrative could be defined as a cognitive-semiotic structure that consists of three levels: (a) narration (expression), (b) underlying story (content), and (c) frame-setting (sedimented socio-cultural experiential background). The latter is missing in most classical analyses, but is arguably necessary in this synthetic account of narrative, as I will show in sections 5 and 6 . Hence, I propose the following definitions of the three levels that jointly constitute a narrative.

a) Narration: the actual expression (e.g. street artwork, political cartoon) where one or more semiotic systems are employed.

b) Underlying story: a particular chronological and causal sequence of related events, organized (typically) as beginning, middle and end, which is represented by the narration.

c) Frame-setting: the sedimented socio-cultural experiential background, which shapes human experience and collective memory, and gives perspectives on shared cultural beliefs, histories and myths.

Let us illustrate. In the case of street art, artists have to decide by means of what techniques, colors, strategies, stylistic choices and so on (i.e. narration) to prompt their audiences to reconstruct the underlying story, with the help of previous knowledge about formerly "told" stories as well as more general frame-settings. In single static images, the narration will be very often strongly underspecified with respect to the underlying story, and can indeed be understood as narration only if the audience is already familiar with the story in advance by bringing certain information to the image and filling in the narrative with their own understandings and interpretations. As Schmid (2005, p.433) has argued, "a single picture can never actually represent a narrative but at best metonymically point to a story."

This leads us to the second crucial question, which is also largely debatable in narrative research: what is narrativity? ${ }^{8}$ Given that narrative was defined as a structure above, narrativity can be understood as the process that "unfreezes" this structure, either from the perspective of the creator or the audience. In that sense, narrativity is something that we perform, both when

\footnotetext{
${ }^{7}$ On the concept of experientiality and experiential background, see also Alber and Fludernik (2011) and Caracciolo (2013, 2014). On the central notion, Caracciolo (2014, p.207) writes: "[...] experience is a powerfully integrative notion, spanning a wide gamut of response, from bodily awareness to the expanse of perception to the intricacies of social interaction and cultural interpretation."

${ }^{8}$ As pointed out by an anonymous reviewer the need for explicit and motivated definitions of such key notions is crucially important.
} 
we produce and when we interpret narratives. Given the concepts defined above, a categorical distinction between two idealized kinds of narrativity in narrative understanding can be proposed $:^{9}$

- Primary narrativity: understanding the narrative by going from narration to the underlying story, under the constraints of the frame-setting.

- Secondary narrativity: understanding the narrative by going from underlying story to the narration, under the constraints of the frame-setting.

It should be noted that these definitions are general enough to apply to any semiotic system, and can perhaps help resolve long-standing debates. For example, the sentence "the king died" can never be a narrative per se, but could be a (part of) narration if it helps trigger a corresponding story (e.g. an episode in Game of Thrones), a clear case of secondary narrativity. On the other hand, a narration such as a fairy-tale, or a sequence of images, such as the well-known "frog story" in Frog Where Are you? (Berman and Slobin, 1994; Louhema et al. under review) are cases of primary narrativity. The relation between the levels of narrative structure and kinds of narrativity are schematically illustrated in Figure 2.

Turning now to specifically pictorial narrations, we may distinguish between three general types, with increasingly higher role for secondary narrativity (e.g. Ranta, 2011, 2013; Ryan, 2011; Schmid, 2005):

- Serial images: multiple static, distinct images are linked in a narrative series that has a fixed reading order, where temporal continuity and causal relations are clearly represented. Examples: cartoons and image books.

- Single polyphase images: single images showing representations of disparate events where temporal continuity and causal relations are not (clearly) represented, but have to be inferred.

- Single monophase images: single illustrative images in which the underlying story needs to be triggered by a representation of a single event. In this case, temporal and causal relations are also not represented in the narration at all.

\footnotetext{
${ }^{9}$ These are analogous, but not identical to the distinction between primary and secondary iconicity (Sonesson, 1997). In the first case one first perceives the similarity between expression and content, and then understands the first as representing the latter. In the second, one has to know that an expression is a sign, to perceive the similarity.
} 


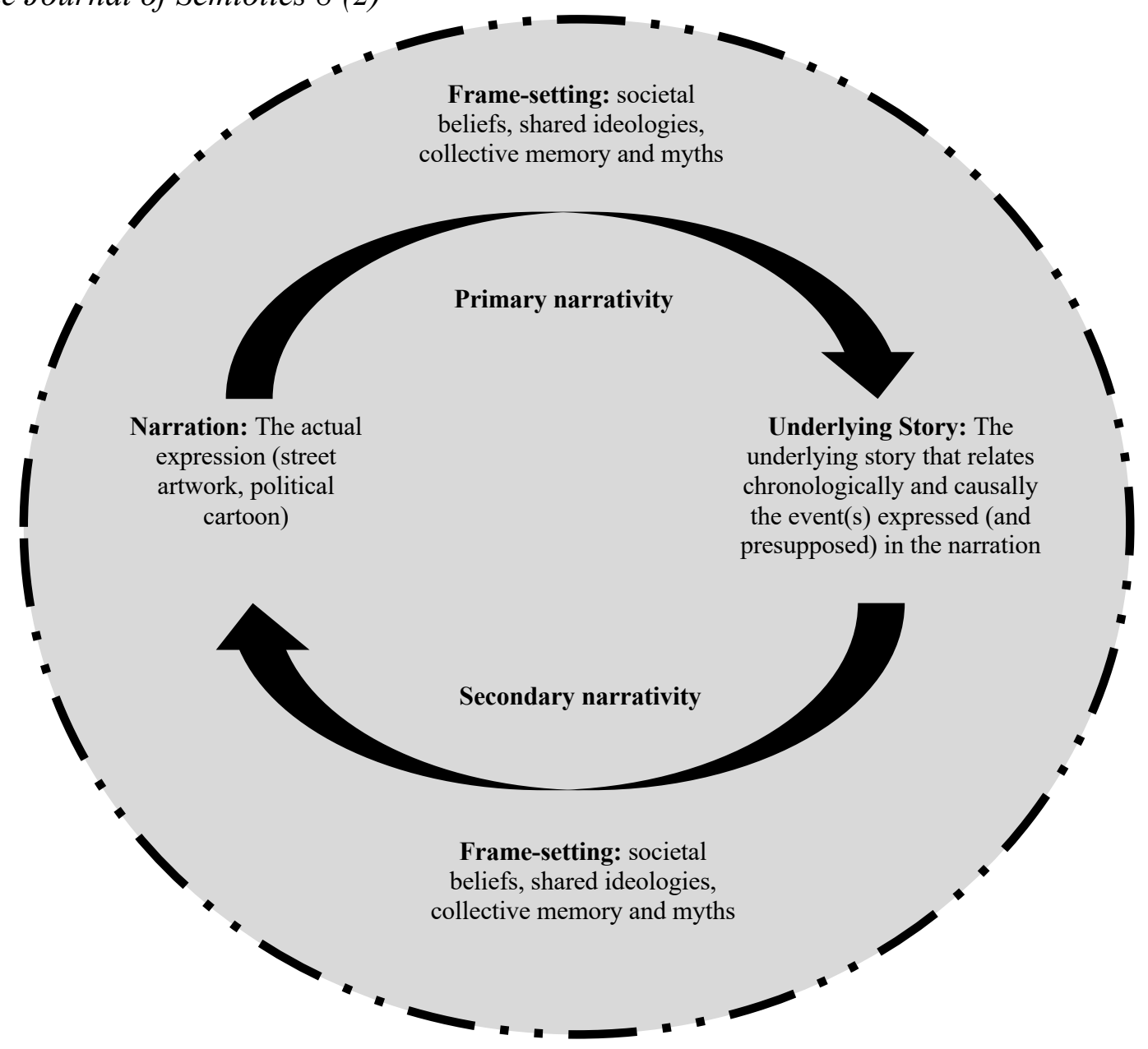

Figure 2. Levels of narrative with primary and secondary narrativity, based on a synthetic account of narrative.

In the case of street art, it is the type of single monophase images that are most often employed. The beholder needs to know the story in advance to be able to make sense of the expression as narration. As stated by Schmid (2005, p.432) such narrations are "dependent on something that lies outside themselves, namely on stories that are derived from another medium and whose identification would frequently be difficult without the captions beneath the images."

In other words, the meaning of such street art narrations would remain highly ambiguous, enigmatic and variously interpretable, unless they can be linked with pre-existing stories, under the constraints of contextual and historical knowledge. Without the background information (frame-setting), the content of the single static image would be puzzling. An audience who has no familiarity with the implied underlying stories (under the constraints of the frame-setting) may come to some kind of understanding of what the street art narrations are about, but arguably not to an intersubjective experience-based interpretation.

As shown in the following sections, a number of images depict in various ways antagonistic situations between Greece and external threats, past or present. Knowledge of these situations and histories, is essential for understanding the images as narrations: the underlying story is a pre-condition for understanding the narration. Such underlying stories presume an initial period of peace, followed by war, sometimes including even glorious defeat, but ending with ultimate victory. This tripartite correlation corresponds to the fundamental structure of (underlying) stories, with beginning, middle and end (Allen, 2013), recognized since antiquity (Aristotle, $335 \mathrm{BC} / 1812$ ). It also instantiates one of the classical models of a prototypical narrative, with a sequence of five stages: (a) an initial equilibrium, (b) a phase of disturbance or 
disruption, (c) a recognition of the disruption and (d) attempts to repair that disturbance, (e) the equilibrium has been restored (Todorov, 1971).

Part of the socio-cultural frame-setting is the collective memory that the Greeks were overpowered, but still resistant and brave Patriots against threatening and Powerful Enemies. Once again, the present notion of frame-setting may be used as an umbrella notion under which societal beliefs, shared ideologies and collective memory, sedimented histories and myths provide explanations and patterns for cultural life and social/moral structure. Such framesettings may generalize over specific underlying stories, and thus, provide historical and existential explanations that may attempt to preserve or challenge power relations. This will be described in sections 5 and 6 , after first providing some necessary socio-political background in the following section.

\section{Providing Context: Greek Street Art Since the 2008 Crisis}

Street art is a popular form of artistic and usually highly sophisticated expression and protest across Greece, involving people of different ages and social classes. The practice of writing and painting on the Greek public walls increased dramatically during the period of Greek crisis, affecting in one way or another the everyday experiences of people. The opposition against the control mechanisms required by the "European troika," i.e. the International Monetary Fund (IMF), the European Commission (EC) and the European Central Bank (ECB), became evident by an abundant production of wall paintings. Hence, street art practitioners and activists claimed their right to participate in the visual construction and reproduction of the "publicly accessible space" (Bengtsen, 2018, p.125). In other words, the street art world of Athens has become a cultural messenger of the everyday experiences during the years of crisis and austerity. Thus, it can elucidate many occurring socio-political and cultural displacements, as the Greek crisis (initially financial, but subsequently also social and political), since its outset in 2008, has prompted an immense number of new waves of street art across the country, not only in the larger cities (Stampoulidis et al., 2018). As Lefebvre (1970/2003, p.19) clearly states, wall paintings can be regarded as symptoms of conflicts and harsh times in urban contexts:

The urban space of the street is a place for talk, given over as much to the exchange of words and signs as it is to the exchange of things. A place where speech becomes writing. A place where speech can become "savage" and by escaping rules and institutions, inscribe itself on walls.

Street art then can be understood as an expression of Lefebvre's demand for the "right to the city" (Lefebvre, 1968/1972). As it is continuously in the process of being made and remade (open and ephemeral), street art provides alternative and dynamic ways of forming the city - not just for and by those who actively write or paint on walls, but also those, who actively engage themselves by viewing and interpreting it.

As I had discussed elsewhere (Stampoulidis 2016) the crisis of the contemporary political system, characterized as the failure of politics to address the needs and demands of citizens, has strongly affected social structures. Therefore, the political instability and insecurity of citizens lead to mass protests in traffic areas (areas with high visibility), riots and continuous strike actions. As the European troika agreed on bailout packages for Greece, income reductions were unexpectedly announced and thousands of Greek citizens went out on the streets in order to express their collective frustration (Goutsos and Polymeneas, 2014; Matsaganis, 2013).

In the following citations (translated by myself from Greek), two Athens-based street artists, who were interviewed in 2015, admit that the crisis has influenced their art in a direct way: 
Since 2008 I have created a series of works related to the crisis, but not as a straight commentary. I prefer to create allegorical images, borrowing from historical events similar to the ones in the present, philosophical research, poetry and quotes, which I alter usually to create an obscure meaning; my aim is to link the present with the past somehow. Always the past can teach us and drives us in the future. (Artist a, March 2015)

As a part of Greek reality, I cannot and I do not want to ignore what is happening in the society through all these years of austerity. The increase of poverty, the increase of homeless people, the increase of unemployment, the increase of suicides, the rise of a neo-Nazi party, I just cannot close my eyes [...] Most of my works are inspired by social phenomena such as poverty, unemployment, injustice [...] Athens is characterized by a sweet chaos that makes her so vivid! I love this kind of chaos, because it gives me unexpectable inspiration. (Artist b, February 2015)

In sum, Greek street art since 2008 or so has been motivated by the specific context of the recent Greek crisis, and the walls have become interactive devices of participatory engagement for socio-political dialogue. The urban environment and the historical period in question are thus crucial for conceptualizing street art in situ and for interpreting its explicit and implicit messages.

\section{Stories of Resistance I: Contemporary Greek Street Art}

As present-day street art has been used as a means of Greek resistance against austerity policies, street artists frequently incorporate elements belonging to something of a nostalgic tradition of Greek resistance starting from antiquity, through the Greek war of independence (1821-1832) to the German Occupation (1941-1944). Thus, they can be said to interconnect the collective memory of significant historical events with modern Greece, urging people to resist control mechanisms and restrictions initiated by the Powerful Other. In other words, street art as a form of spatial politics and creative reaction becomes an incarnation of the Greek tradition of resistance and revolt.

In this section the qualitative analyses of three images as exemplary cases of single event representations from the corpus of 45 images are presented. Each of these three exemplary images prompts different underlying stories. The criteria on which these three examples were selected were: (a) single event representations that may prompt underlying stories with the help of secondary narrativity and (b) significance of socio-cultural and contextual information for the narratological interpretation.

The poster by the artist Absent (Figure 3) depicts a Greek protester/fighter dressed up with the traditional pleated skirt-like garment (fustanella), the particular type of footwear called tsarouhi, as well as the traditional uniform worn by the Greek guards in front of the Greek parliament today. In the depicted scene, he is about to throw something resembling a Molotov cocktail in the form of a euro sign. This work alludes to the historical past of Greece and the untamed spirit of its people during the (successful) war of independence against the Turks and the Ottoman Empire (1821-1832). ${ }^{10}$ The fighter is represented metonymically as a personification of Greece, trying either to throw away its connectedness to the EU or perhaps to fight against the EU in order to regain independence. Regarded as a single event representation, we can easily imagine a "before-state" of inactivity as well as an "after-state," where the target becomes harmed or even destroyed. The exact target of the warrior's attack remains

\footnotetext{
${ }^{10}$ The Greek Independence Day, March 25, nowadays a national holiday, commemorates the resulting formation of an independent state. The specific date that this artwork was created, according to the artist, was March 21, 2012, that is, a couple of days before the holiday.
} 
unidentifiable, though the work seems to indicate some kind of delightful resistance, by reminding us the Banksy's widely recognizable work "Rage, Flower Thrower," where the character's position is exactly the same with the Greek warrior in Figure $3 .^{11}$ In addition, the image may be regarded as an artistic statement denoting the analogy between the glorious Greek past and the difficult contemporary times with austerity measures, fiscal policies and EU "supervision" on the other.

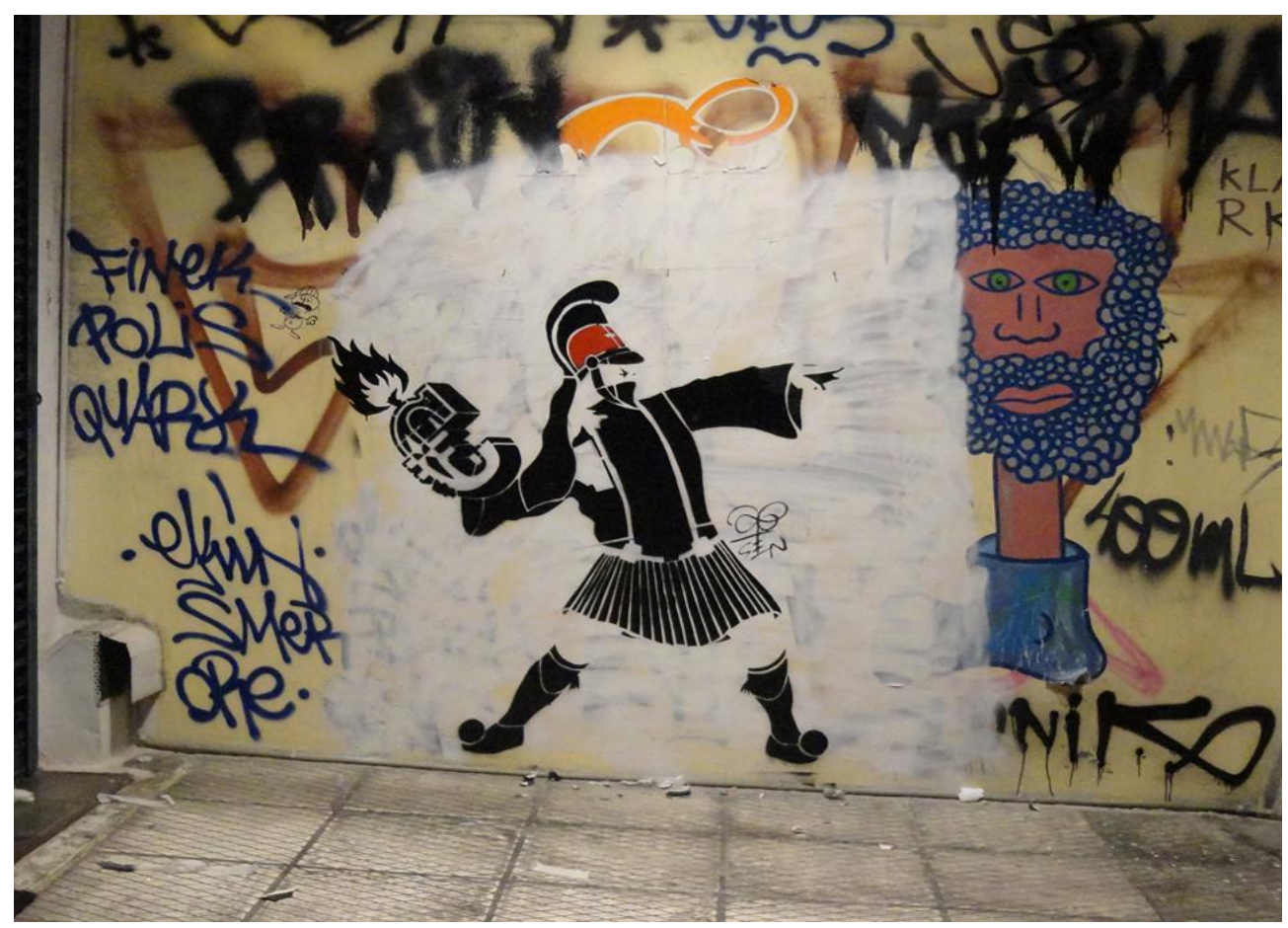

Figure 3. Greek guard with €-Molotov cocktail. Artist-creator: Absent. Area: Monastiraki, 2012. Photo courtesy of the artist (C).

Figure 4 shows an artwork depicting Aristotle holding a Molotov cocktail, probably also in an act of throwing it. The caption above reads "Poverty is the parent of revolution and crime," which is a widespread well-known quotation from Aristotle's Politics. The choice of here representing one of the most influential and authoritative figures in Greek (and Western) philosophy, in combination with the verbal intertext, could be seen as a metaphor of the current Greek state of crisis after the consecutive years of economic hardship. Thus, this image could be narratologically interpreted as an artistic protest emphasizing the right to rebel for the Greek people, who have suffered during this period. Aristotle's political philosophy has had a strong influence throughout Europe during most of the Middle Ages and he has continued to be seen as an important thinker to this very day. Thus, also in this case we may discern a similar underlying story, stretching from Greece' glorious cultural and intellectual past, as here indicated by the depiction of Aristotle (whose halo gives him almost a religious status), to contemporary and future states of resistance and possible resolution.

${ }^{11}$ See URL: http://www.blogs.buprojects.uk/2015-2016/rachelrichardson/2015/12/30/rage-flower-thrower-or-flowerbomber-by-banksy/ (Retrieved 17 June 2019). Also, see Blanché (2015), an expert in British postwar art at the European Institute for Art History in Heidelberg, who has written extensively about Banksy since 2010. 


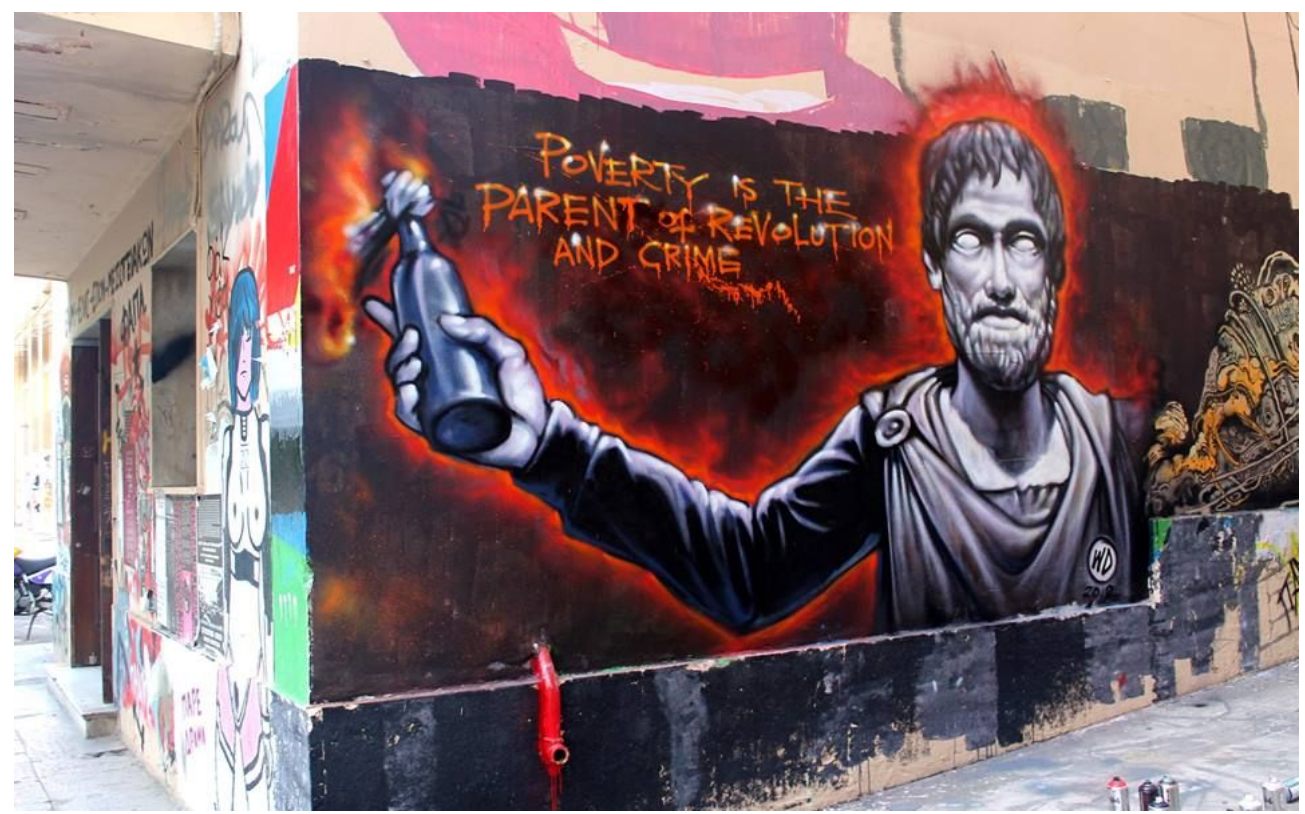

Figure 4. Poverty is the parent of revolution and crime. Artist-creator: WD. Area: Exarchia, 2012. Photo courtesy of the artist (C.

In the same vein, Figure 5 depicts the widely recognizable Athena, the ancient Greek goddess of wisdom, inspiration, heroic battle and strength, as well as the patron goddess of the city of Athens itself. In the image, Athena is holding a flag with the caption "Revolution"

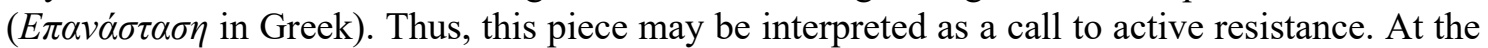
same time, by bringing together ancient and modern layers of history (as in Figure 3 and 4), the artist Bleeps.gr may be capturing some of the main tensions of modern Greek identity: trapped between the ruins of an ancient glorious past and the uncertainties and difficulties of a precarious future. Again, this underlying story maps the historical past of classical antiquity with its cultural ideals to the peaceful past, and implies a possible future resolution of the present conflict.

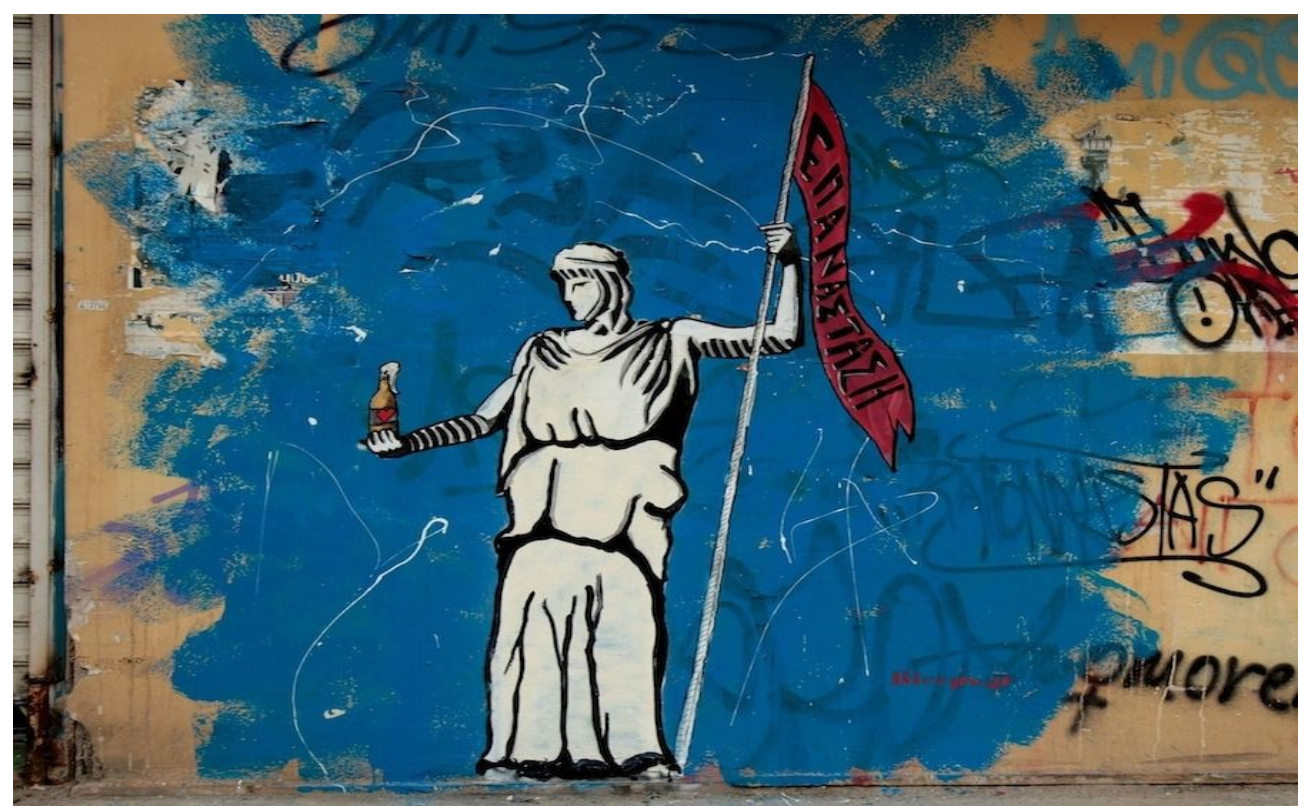

Figure 5. Revolution. Artist-creator: Bleeps.gr. Area: Thiseio, 2011. Photo courtesy of the artist (C). 
It is straightforward to identify the narratological pattern of secondary narrativity in all three cases. The underlying story, as well as the deeply sedimented historical collective memory and socio-cultural background (frame-setting), is required in order to understand the narration. For example, in Figure 3 a single event representation (narration) can help trigger an underlying story of the kind that was presented, but only with the help of the frame-setting that all preceding examples share, namely Greece vs. Powerful Enemy. In the same vein, these three forms of revolutionary street artworks seem to show "figures of rebels" (Zaimakis, 2015, p.387) with a fighting spirit and ready for actions of resistance during the current Greek economic crisis. To offer some possible generalizations, street artists as political activists express "stories of resistance" by employing:

- Iconic or popular figures of Greek history (a Greek fighter, Figure 3; an ancient Greek philosopher and scientist, as Aristotle, Figure 4; and an ancient Greek goddess, possibly Athena, Figure 5).

- Allusions to historical events and widespread stories (e.g. the Greek War of Independence, Figure 3; and classical antiquity ideals and values, Figures 4 and 5).

- Revolutionary slogans and symbols (e.g. the euro sign, Molotov cocktail, rebellious calls).

To sum up, many current street artworks in Athens reflect the problematic tensions of the last decade. These achieve additional socio-political weight through their intertextual references to widespread and historically persistent stories of resistance. However, rooted within a specific tradition, socio-political street art may not be fully appreciated outside of the broader context of preceding graphic representations, such as political cartoons from the 1940s during the German occupation. Political cartoons constitute a highly suitable candidate genre for expressing sociopolitical issues in a simple and broadly conceivable manner, since, as stated by Duus (2001, p.995), they:

... reveal a side of political culture not found in official memoranda, public speeches and newspaper editorials, theoretical tracts, and ideological pamphlets. They provide access to "everyday" reactions to politics that even public opinion polls cannot capture.

In order to allow for comparison with contemporary Greek street art, which is the main focus of this article, two exemplary cases of political cartoons from the 1940s are examined in order to test the proposed conceptual schema (Figure 2) about the underlying stories that may be shared by those two different forms of creative resistance, belonging to different temporal conditions. Hence, the relationship between these two divergent forms of protest (street artworks and political cartoons) becomes even more apparent when we think about the fact that they seem to trigger the same sedimented socio-cultural frame-setting and "the right to resistance."

\section{Stories of Resistance II: Political cartoons (1941-1944)}

Resistance movements in Greece were organized during the German invasion and occupation, which began in April 1941. The first major resistance group and political movement was the National Liberation Front (Ethniko Apeleftherotiko Metopo, EAM) (Chimbos, 2003, p.29). During the German occupation, resistance groups of various sizes encouraged Greeks to revolt against the Nazis (Chimbos, 2003, p.29; Tsoumas, 2011). During WWII various media related to the Greek resistance (within and outside Greece), such as newspapers including political 
cartoons, played a significant role in informing, motivating and triggering the public and its behavior. Recurring themes of these cartoons focused on rebellion, patriotism and heroism, as well as ridiculing the enemy (Chimbos, 2003) and intentionally making use of value-laden symbols and emblems, like the traditional Greek uniform and the Nazi swastika.

Figure 6, a cartoon from the 1940s, displays a Greek fighter as a personification of Greece, facing a vast mountainous terrain covered by a swastika. The somewhat fierce-looking fighter seems to protect and defend the country's borders, while the threat of Nazism and fascism has already reached the neighboring countries and endangers Greece. Interestingly, the amplification of size of the swastika compared to the much smaller Greek fighter suggests an implied unequal conflict between Greek protagonists as resistant and courageous rebels against the overpowering antagonist Nazis.

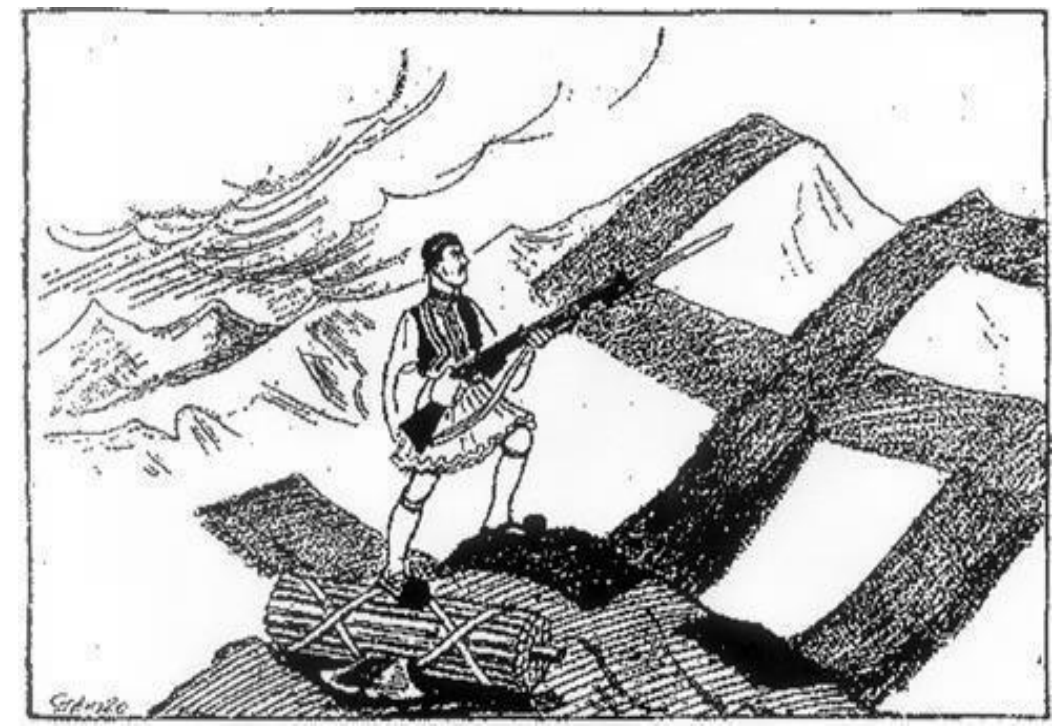

Figure 6. Example of political cartoon (1940s). Greek resistance. (Retrieved 17 June 2019 from http://users.sch.gr/pchaloul/geloiografies.htm)

Another cartoon (Figure 7) displays two distinct spatiotemporal events from the area of Thermopylae (as the caption reveals) which had been a battlefield between Greek fighters and invading enemies in several occasions, such as Persians in antiquity (Thermopylae $480 \mathrm{BC}$ ) and Germans in the 1940s (Thermopylae 1941). ${ }^{12}$ The Greek-Persian Battle of Thermopylae is perhaps the most famous one in Greek history. The invasion of the Persian Empire of Xerxes with huge troops, recently popularized by the film 300 is a clear case of arrogant aggression. ${ }^{13}$ On the other hand, the heroism of the Spartan king Leonidas with his relatively small army is a world-famous example of altruistic heroism. Thus, the WWII battle of Thermopylae is here related to its ancient predecessor, where Leonidas with a small force fought to the death against the overwhelming Persian army.

\footnotetext{
12 The historical context is that during the German Occupation and more specifically in April 1941, the German army invaded Greece, violating its northern borders. The British forces and allies in the country were unable to hold back the German advance, so it was decided to withdraw them. New Zealand and Australian troops took positions in Thermopylae to delay the Nazi troops by applying a strategy similar to that of Spartans.

${ }^{13}$ See URL: https://www.imdb.com/title/tt0416449/ (Retrieved 17 June 2019).
} 


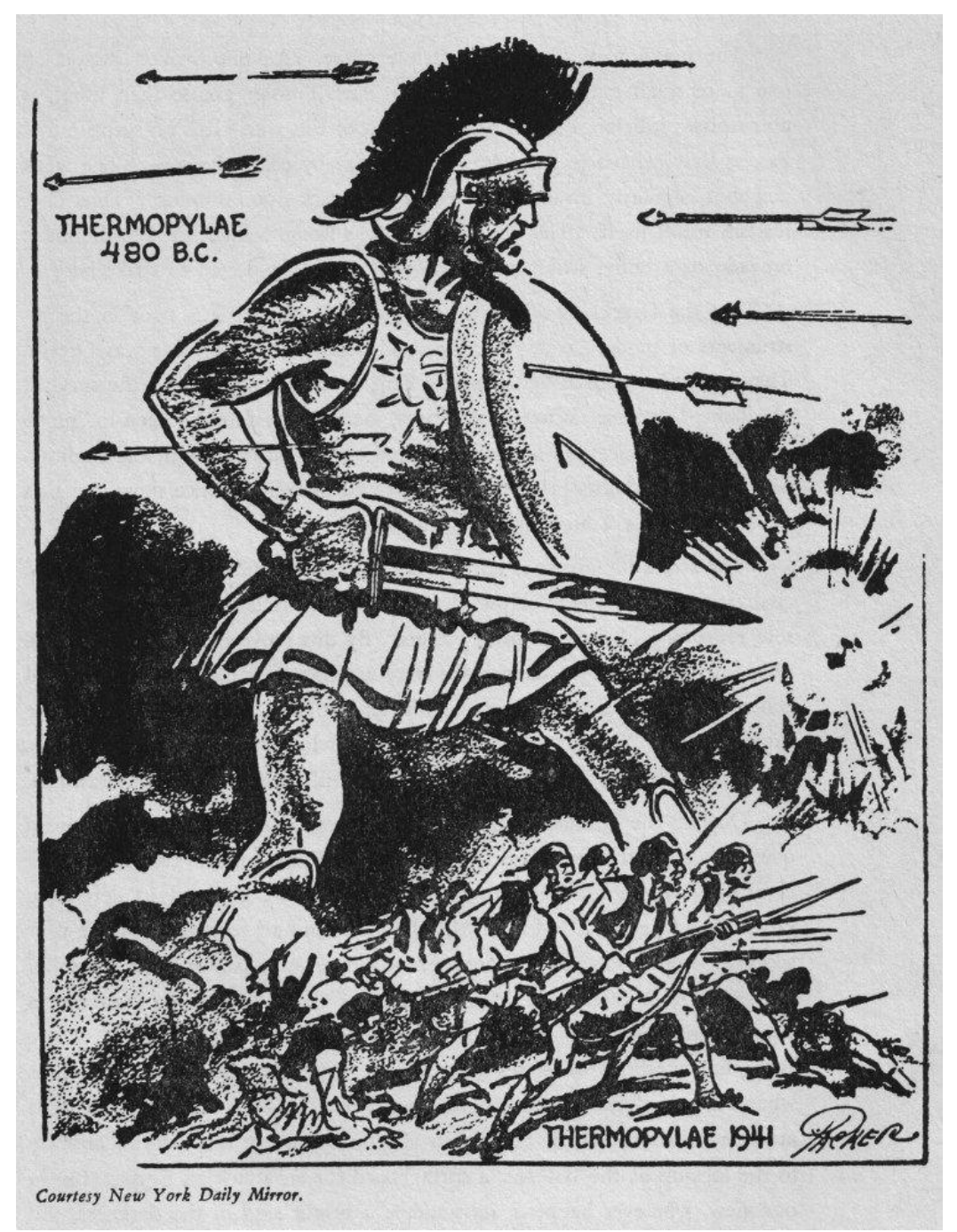

Figure 7. Example of political cartoon (1940s). Greek resistance.

Thermopylae 480 BC. Thermopylae 1941. Photo courtesy of New York Daily Mirror 1924-1957 C).

We may generalize that these two cartoons instantiate the same frame-setting, where Greece is presented as a resistant Hero against a Powerful Enemy (e.g. present European Troika, Figures 3, 4, 5; Turks, Figure 3; Nazis, Figures 6, 7; Persians, Figure 7), as can be schematically illustrated in Figure 8. 


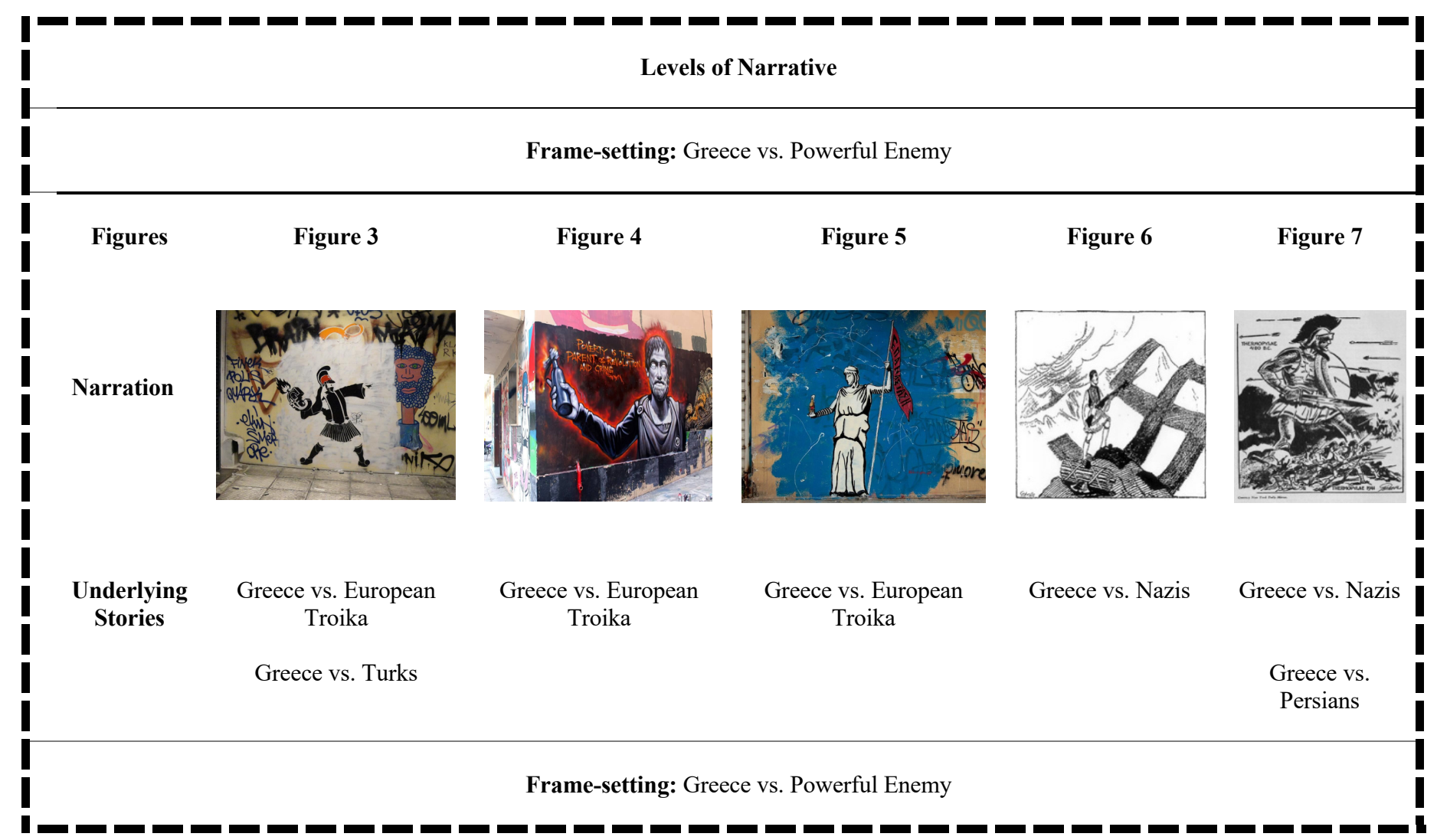

Figure 8. Applying the narrative schema (Figure 2) to the five images.

\section{Conclusions}

This paper has examined the narrative potential of images in two divergent media: contemporary Greek street art and older political cartoons. During politically intense periods contemporary street art as well as other expressions of resistance from the past (as manifested in e.g. political cartoons) acquire socio-political dynamics in the changing of socio-political (urban) space. It was shown that the five exemplary cases (Figures 3-7) analyzed are all involved in different kinds of narration, and at the same time demonstrate two common properties. First, as arguably all single images, they gain their status as narrations by presupposing common knowledge of a culturally shared story. Second, all of these images can be said to instantiate a deeply sedimented socio-cultural frame-setting, where Greece confronts a Powerful Enemy.

Theoretically, the main contribution of this paper is a synthetic cognitive-semiotic account of the important but controversial notion of narrative (in street art, and more generally), which distinguishes between three levels: narration (the expression), the underlying story (the content) and the frame-setting (the background). It was also assumed that the structure of the underlying story corresponds to the basic structure of beginning, middle and end, which also maps onto the well-known five-stage schema proposed by Todorov (1971), as shown in Table 1. 
Table 1. Mapping Todorov's five narrative stages and the tripartite schema of beginning, middle and end to the content of the analyzed images.

\begin{tabular}{|c|c|c|c|c|}
\hline $\begin{array}{c}\text { Stage 1 } \\
\text { Equilibrium }\end{array}$ & $\begin{array}{c}\text { Stage } 2 \\
\text { Disruption }\end{array}$ & $\begin{array}{c}\text { Stage } 3 \\
\text { Recognition }\end{array}$ & $\begin{array}{l}\text { Stage } 4 \\
\text { Repair }\end{array}$ & $\begin{array}{c}\text { Stage } 5 \\
\text { New Equilibrium }\end{array}$ \\
\hline $\begin{array}{l}\text { a pseudo historic } \\
\text { idyllic, glorious } \\
\text { Greek past }\end{array}$ & \multicolumn{3}{|c|}{$\begin{array}{l}\text { a past/present filled with obstacles and threats posed by e.g. the } \\
\text { Persians, Turks, Nazis, or the European troika }\end{array}$} & $\begin{array}{c}\text { past/present attempts } \\
\text { to repair that } \\
\text { disturbance, by } \\
\text { means of resistance } \\
\text { and the dream and } \\
\text { promise of a new, } \\
\text { future state of } \\
\text { equilibrium, i.e. a } \\
\text { stable and trouble- } \\
\text { free Greece } \\
\text { (Implicit) }\end{array}$ \\
\hline BEGINNING & \multicolumn{3}{|c|}{ MIDDLE } & END \\
\hline
\end{tabular}

Concerning the different views in narratology and the many theoretical challenges posed by the study of narrative and narrativity, the qualitative analyses of a sample of street artworks and political cartoons support the conclusion that single static images do cannot narrate stories on their own, but rather presuppose such underlying stories, which they can prompt or trigger by relying on the audience's understanding of context and deeply sedimented experiential background. Especially this latter aspect, I have argued, is consistent with both phenomenology and an experiential approach to narratives. The notion of secondary narrativity, implying that as street art interpreters we are compelled to construct the narratives based on what we already know was therefore emphasized.

Although much work has yet to be done in terms of both theoretical analysis and empirical research, this piece of work has provided a starting point for further investigations. For example, it would be fruitful to expand the investigation by studying (a) the role played by the semiotic systems of language, depiction and gesture (considering their limitations and differences) in the formation of polysemiotic narratives (e.g. Louhema et al., under review; Krogh, 2019), and (b) the interplay between narrative and metaphor (e.g. Fitzpatrick and Farquhar, 2019) in street art meaning-making. ${ }^{14}$

\section{Acknowledgements}

I would like to thank Michael Ranta and Göran Sonesson for stimulating and inspiring discussions. I am especially grateful to Jordan Zlatev and Sara Lenninger for extensive feedback on earlier versions of this text. Special thanks are also due to two anonymous reviewers for their perceptive remarks and suggestions in relation to narrative theory and street art research.

14 The question of what is the relationship between narrative and metaphor in meaning-making, their potential complementarity and impact on audience's interpretation of street art lies outside the scope of this paper, and thus, it shall be discussed in another context (Stampoulidis and Zlatev, in preparation). However, for recent research on figurativity in street art see Stampoulidis et al. (2019) and Stampoulidis and Bolognesi (in press). 
Last but not least, special thanks are due to Yiannis Zaimakis, Ricardo Campos and Andrea Pavoni, who have provided editorial advice on earlier versions of the manuscript. All remaining errors are entirely my own responsibility.

\section{References}

Abbott, H. P. (2002). The Cambridge Introduction to Narrative. Cambridge: Cambridge University Press.

Alber, J. and Fludernik, M. (2011). Mediacy and Narrative Mediation. In P. Hühn et al. (Eds.). The Living Handbook of Narratology. Hamburg: Hamburg University Press. Retrieved 5 September 2019 from http://www.lhn.uni-hamburg.de/article/mediacy-and-narrativemediation

Allen, R. J. (2013). Beginning, Middle, End of an Era: Has Technology Trumped Aristotle? Journal of Film and Video 65(1-2): 9-29.

Aristotle. 335 BC/1812. Treatise on Poetry. London, United Kingdom: Luke Hansard and Sons.

Avramidis, K. and Tsilimpounidi, M. (2017). Graffiti and street art: reading, writing and representing the city. London, New York: Routledge.

Awad, S. H. and Wagoner, B. (Eds.). (2017). Street Art of Resistance. Palgrave publishing.

Bal, M. (1997). Narratology: Introduction to the Theory of Narrative. $2^{\text {nd }}$ ed. University of Toronto Press.

Bengtsen, P. (2014). The Street Art World. Lund: Almendros de Granada Press.

Bengtsen, P. (2018). Street art and the nature of the city. In P. Bengtsen and M. Liljefors (Eds.). Bild och natur (pp.125-138). Tio konstvetenskapliga betraktelser 16.

Berman, R. A. and Slobin, D. I. (1994). Relating events in narrative. A crosslinguistic developmental study. Hillsdale, NJ: Lawrence Erlbaum.

Blanché, U. (2015). Street art and related terms - discussion and working definition. Street Art and Urban Creativity Scientific Journal 1(2): 32-39. DOI: https://doi.org/10.25765/sauc.v1i1.14

Bordwell. D. (2007). Poetics of cinema. London, New York: Routledge.

Caracciolo, M. (2013). Experientiality. In P. Hühn et al. (Eds.). The Living Handbook of Narratology. Hamburg: Hamburg University Press. Retrieved 5 September 2019 from http://www.lhn.uni-hamburg.de/article/experientiality

Caracciolo, M. (2014). The Experientiality of Narrative: An Enactivist Approach. Berlin: De Gruyter.

Chaffee, L. G. (1993). Political Protest and Street Art: Popular Tools for Democratization in Hispanic Countries. Westport, CT: Greenwood Press.

Chatman, S. (1978). Story and Discourse: Narrative Structure in Fiction and Film. Ithaca: Cornell University Press.

Chimbos, P. (2003). Women of the 1941-44 Greek resistance against axis: an historical and sociological perspective. Atlantis (28)1: 28-35.

Christiansen, K. (1983). Early Renaissance Narrative Painting in Italy, The Metropolitan Museum of Art Bulletin. Retrieved 5 September 2019 from https://www.metmuseum.org/pubs/bulletins/1/pdf/3259419.pdf.bannered.pdf

Duus, P. (2001). Presidential address: Weapons of the weak, weapons of the strong - the development of the Japanese political cartoon. The Journal of Asian Studies 60(4): 965997.

Ferrel, J. and Weide, R. D. (2010). Spot theory. City: analysis of urban trends, culture, theory, policy, action 14(1-2): 48-62. DOI: https://doi.org/10.1080/13604810903525157

Fitzpatrick E. and Farquhar, S. (2019). Innovations in Narrative and Metaphor. Springer, Singapore.

Fludernik, M. (1996). Towards a "Natural" Narratology. London, New York: Routledge. 
Forceville, C. and Kjeldsen, J. E. (2018). The affordances and constraints of situation and genre: visual and multimodal rhetoric in unusual traffic signs. International Review of Pragmatics 10(2): 158-178. DOI: https://doi.org/10.1163/18773109-01002002

Genette, G. (1988). Narrative Discourse Revisited, transl. J. E. Lewin. Ithaca: Cornell University Press.

Goutsos, D. and Polymeneas, G. (2014). Identity as space Localism in the Greek protests of Syntagma Square. Journal of Language and Politics 13(4): 675-701.

Halbwachs, M. (1992/1952). On collective memory (translated and edited by L. A. Coser). Chicago: University of Chicago Press.

Hansen, S and Flynn, D. (2016). "Darling Look! It's a Banksy!” Viewers' Material Engagement with Street Art and Graffiti. In A. Gralińska-Toborek and W. Kazimierska-Jerzyk (Eds.). Aesthetic Energy of the City. Experiencing Urban Art and Space (pp.103-115). Łódź University Press. DOI: http://dx.doi.org/10.18778/8088-151-8.06

Harvey, D. (2000). Spaces of hope. California: University of California Press.

Hoppe, I. (2014). Urban Art as Countervisuality? In P. Soares Neves and D. V. de Freitas Simões (Eds.). Lisbon Street Art and Urban creativity International Conference 2014 (pp.260-265). Lisbon: Authors and Editors.

Krogh Diget, I. S. (2019). Intersemiotic Translation from Film to Audio Description: A cognitive semiotic approach. MA Thesis. Lund University.

Kusenbach, M. (2003). Street Phenomenology: The Go-Along as Ethnographic Research Tool. Ethnography 4(455): 455-485.

Lefebvre, H. (1968/1972). Le Droit à la ville suivi de Espace et politique. Paris: Anthropos.

Lefebvre, H. (1970/2003). The Urban Revolution. Minnesota: Minnesota University Press.

Levi-Strauss, C. (1973/1967). From Honey to Ashes: Introduction to a Science of Mythology. Volume 2, London, Jonathan Cape.

Lewisohn, C. (2008). Street Art: The Graffiti Revolution. New York: Abrams.

Louhema, K., Zlatev, J., Graziano, M. and van de Weijer, J. (Under review). Translating from unisemiotic to polysemiotic narratives: A study of Finnish speech and gestures. Sign Systems Studies.

Matsaganis, M. (2013). The Greek Crisis: Social Impact and Policy Responses. Berlin: Friedrich Ebert Stiftung.

Novy J. and Colomp, C. (2013). Struggling for the Right to the (Creative) City in Berlin and Hamburg: New Urban Social Movements, New 'Spaces of Hope'? International Journal of Urban and Regional Research 37(5): 1816-1838. DOI: https://doi.org/10.1111/j.14682427.2012.01115.x

Philipps, A. (2015). Defining Visual Street Art: In Contrast to Political Stencils. Visual Anthropology 28(1): 51-66.

Pollio, H., Henley, T. and Thompson, C. B. (1997). The phenomenology of everyday life. Cambridge University Press.

Popova, Y. (2015). Stories, Meaning, and Experience: Narrativity and Enaction. London, New York: Routledge.

Prince, G. (1982). Narratology: The Form and Functioning of Narrative. Berlin: De Gruyter.

Prince, G. (2008). Narrativehood, narrativeness, narrativity, narratability. In J. Pier and J. A. Landa (Eds.). Theorizing narrativity (pp.19-27). Berlin: De Gruyter.

Propp, V. (1928/1968). Morphology of the Folk Tale. Austin, Texas, United States: University of Texas Press.

Ranta, M. (2011). Stories in pictures (and non-pictorial objects) - A narratological and cognitive psychological approach. Contemporary Aesthetics 9.

Ranta, M. (2013). (Re-)Creating Order: Narrativity and Implied World Views in Pictures. Storyworlds: A Journal of Narrative Studies 5: 1-30.

Ross, J. I., Bengtsen, P., Lennon, J. F., Phillips, S., and Wilson, J. Z. (2017). In search of academic legitimacy: The current state of scholarship on graffiti and street art. The Social Science Journal 54: 411-419. DOI: https://doi.org/10.1016/j.soscij.2017.08.004 
Ryan, M. L. (2007). Toward a definition of narrative. In D. Herman (Ed.). The Cambridge companion to narrative (pp.22-35). Cambridge: Cambridge University Press.

Ryan, M. L. (2011). Narration in Various Media. In P. Hühn et al. (Eds.). The Living Handbook of Narratology. Hamburg: Hamburg University Press. Retrieved 17 June 2019 from https://www.lhn.uni-hamburg.de/node/53.html

Schmid, W. (2005). Pictorial narrativity. In D. Herman et al. (Eds.). Routledge encyclopedia of narrative theory (pp.431-435). London, New York: Routledge.

Schmid, W. (2010). Narratology. An Introduction. Berlin: De Gruyter.

Sokolowski, R. (2000). Introduction to Phenomenology. Cambridge: Cambridge University Press.

Sokolowski, R. (2008). Phenomenology of the Human Person. Cambridge: Cambridge University Press.

Sonesson, G. (1997). Mute narratives. New issues in the study of pictorial texts. In Lagerroth U.-B., Lund H., and Hedling E. (Eds.). Interart Poetics. Acts of the congress "Interart Studies: New Perspectives" (pp.243-252). Rodophi, Amsterdam and Atlanta.

Sonesson, G. (2009). The view from Husserl's lectern: Considerations on the role of phenomenology in cognitive semiotics. Cybernetics and Human Knowing 16(3-4): 107148.

Stam, R., Burgoyne, R. and Flitterman-Lewis, S. (1992). New vocabularies in film semiotics: structuralism, post-structuralism, and beyond. London, New York: Routledge.

Stampoulidis, G. (2016). Hope Wanted: Wall Writing Protests in Times of Economic Crisis in Athens. Lund University Press, Sweden.

Stampoulidis, G., Bitouni, T. and Xyntarianos-Tsiropinas, P. (2018). The "black-and-white mural" in Polytechneio: Meaning-making, materiality, and heritagization of contemporary street art in Athens. Street Art and Urban Creativity Scientific Journal 4(2): 54-65. DOI: https://doi.org/10.25765/sauc.v4i2.143

Stampoulidis, G., Bolognesi, M. and Zlatev, J. (2019). A cognitive semiotic exploration of metaphors in Greek street art. Cognitive Semiotics 12(1). DOI: https://doi.org/10.1515/cogsem-2019-2008

Stampoulidis, G. and Bolognesi, M. (In press). Bringing metaphors back to the streets: A corpus-based study for the identification and interpretation of rhetorical figures in street art. Visual Communication.

Todorov, T. (1969). Structural Analysis of Narrative. NOVEL: A Forum on Fiction 3(1): 70-76.

Todorov, T. (1971). Poétique de la prose. Paris: Seuil.

Tsoumas, J. (2011). The aesthetic impact of graffiti art on modern Greek urban landscape. Ángulo Recto. Revista de estudios sobre la ciudad como espacio plural 3(2): 17-35. DOI: http://dx.doi.org/10.5209/rev ANRE.2011.v3.n2.37576

Tulke, J. (2016). Tales of Crisis from the Walls of Athens. An Exploration of Urban Austerity through the Cultural Practice of Street Art. In B. Schönig and S. Schipper (Eds.). Urban Austerity. Impacts of the Global Financial Crisis on Cities in Europe (pp.257-270). Theater Der Zeit: Frankfurt.

Young, A. (2016). Street Art World. New York: Reaktion Books.

Vercauteren, G. (2012). A narratological approach to content selection in audio description: towards a strategy for the description of narratological time. MonTI 4: 207-231.

Wertsch, J. (2002). Voices of collective remembering. Cambridge: Cambridge University Press.

Zaimakis, Y. (2015). 'Welcome to the civilization of fear': on political graffiti heterotopias in Greece in times of crisis. Visual Communication 14(4): 373-396.

Zlatev, J. (2015). Cognitive semiotics. In P. Trifonas (Ed.). International handbook of semiotics (pp.1043-1067). Dordrecht, Netherlands: Springer.

Zlatev, J. (2019). Mimesis theory, learning, and polysemiotic communication. In M. A. Peters (Ed.). Encyclopedia of educational philosophy and theory (pp.1-6). Singapore: Springer Science and Business Media. DOI: https://doi.org/10.1007/978-981-287-532-7 672-1 
Zlatev, J., Sonesson, G. and Konderak, P. (Eds.) (2016). Introduction: Cognitive semiotics comes of age. In G. Sonesson, P. Konderak and J. Zlatev (Eds.). Meaning, Mind and Communication: Explorations in Cognitive Semiotics (pp.9-28). Peter Lang Publishing Group.

\section{Author Address}

Lund University, Centre for Language and Literature, Division for Cognitive Semiotics, Lund, Sweden Email: georgios.stampoulidis@semiotik.lu.se

\section{About the author}

Georgios Stampoulidis is a $\mathrm{PhD}$ candidate at the Division for Cognitive Semiotics at Lund University. His research interests are in the fields of polysemiotic communication and multimodality, narrative and metaphor, and urban creativity. His work focuses on street art as a cross-cultural medium of meaning-making, cultural production and political intervention in urban space, and thus, he has previously conducted fieldwork in Athens, Greece. His most recent publications are "A Cognitive Semiotic Exploration of Metaphors in Greek Street Art" (Cognitive Semiotics, 2019) and "Urban Creativity in Abandoned Places. Xenia Hotels Project, Greece" (Nuart Journal, 2019). Currently, he is research fellow at Urban Creativity Lund and Scandinavian Metaphor networks. 